\title{
Simultaneous Intercalation of 1-Naphthylacetic Acid and Indole-3-butyric Acid into Layered Double Hydroxides and Controlled Release Properties
}

\author{
Shifeng Li, ${ }^{1,2}$ Yanming Shen, ${ }^{2}$ Min Xiao, ${ }^{3}$ Dongbin Liu, ${ }^{2}$ Lihui Fan, ${ }^{2}$ and Zhigang Zhang ${ }^{1}$ \\ ${ }^{1}$ Liaoning Provincial Key Laboratory of Chemical Separation Technology, Shenyang University of Chemical Technology, \\ Shenyang 110142, China \\ ${ }^{2}$ College of Chemical Engineering, Shenyang University of Chemical Technology, Shenyang 110142, China \\ ${ }^{3}$ Department of Environmental Engineering, Shenyang University, Shenyang 110044, China
}

Correspondence should be addressed to Shifeng Li; li.shi.feng@163.com

Received 11 March 2014; Revised 17 April 2014; Accepted 18 April 2014; Published 18 May 2014

Academic Editor: Chunyi Zhi

Copyright (C) 2014 Shifeng Li et al. This is an open access article distributed under the Creative Commons Attribution License, which permits unrestricted use, distribution, and reproduction in any medium, provided the original work is properly cited.

\begin{abstract}
Controlled release formulations have been shown to have potential in overcoming the drawbacks of conventional plant growth regulators formulations. A controlled-release formulation of 1-naphthylacetic acid (NAA) and indole-3-butyric acid (IBA) simultaneous intercalated MgAl-layered double hydroxides (LDHs) was prepared. The synthetic nanohybrid material was characterized by various techniques, and release kinetics was studied. NAA and IBA anions located in the gallery of MgAl-LDHs with bilayer arrangement, and the nanohybrids particles were of typical plate-like shape with the lateral size of 50-100 nm. The results revealed that NAA and IBA have been intercalated into the interlayer spaces of MgAl-LDHs. The release of NAA and IBA fits pseudo-second-order model and is dependent on temperature, $\mathrm{pH}$ value, and release medium. The nanohybrids of NAA and IBA simultaneously intercalated in LDHs possessed good controlled release properties.
\end{abstract}

\section{Introduction}

In recent years, plant growth regulators (PGRs) including indole-3-butyric acid (IBA) and 1-naphthalene acetic acid ( $\alpha$ NAA) are widely used in agriculture to increase plant growth and reproduction $[1,2]$. Although PGRs found their way into wide applications and have played a significant part in constantly boosting agricultural production, the hazards they have brought along with them to food safety and human health have increasingly become the focus of world attention [3-5]. Controlled release formulations (CRFs) have been shown to have potential in overcoming the drawbacks of conventional PGRs formulations, since they allow usage of minimum amount of PGRs for the same activity. Many research efforts have been devoted to developing controlled release formulations for PGRs, mainly using microencapsulation and inorganic material technology [6-12]. Recently, layered double hydroxides (LDHs) have attracted intensive attentions because of their potential in functional materials
[13-22]. The layered double hydroxides (LDHs), also known as hydrotalcite-like compounds, are a class of anionic clays whose structures are based on brucite-like layers. LDHs have the general formula $\left.\left[\mathrm{M}_{1-x}^{\mathrm{II}} \mathrm{M}_{x}^{\mathrm{III}}(\mathrm{OH})_{2}\right]^{x+}\left(\mathrm{A}^{n-}\right)_{x / n}\right] \cdot m \mathrm{H}_{2} \mathrm{O}$, whereby $\mathrm{M}^{\mathrm{II}}$ are divalent, $\mathrm{M}^{\mathrm{III}}$ are trivalent metal cations, and A represents the intercalated anion [23]. The application of plant growth regulators intercalated LDHs has been reported. Hussein et al. [8-10] first reported the synthesis of $\alpha$ naphthaleneacetate, indole-2-carboxylate intercalated LDHs and interpreted the release mechanism. Most recently, Qiu and Hou [12] prepared the indole-3-butyric acid intercalated LDHs and studied the release kinetics. However, in several cases a concurrent controlled release of these two herbicides is necessary $[24,25]$. To our knowledge, the preparation and simultaneous controlled release of NAA and IBA anions from LDHs interlayer have not been reported in the literature. Therefore, in the present work, NAA and IBA cointercalation into the interlayer of MgAl-LDHs is prepared. The 
synthetic nanohybrid material was characterized by various techniques, and release kinetics was studied.

\section{Experimental}

2.1. Materials. $\mathrm{Mg}\left(\mathrm{NO}_{3}\right)_{2} \cdot 6 \mathrm{H}_{2} \mathrm{O}, \mathrm{Al}\left(\mathrm{NO}_{3}\right)_{3} \cdot 9 \mathrm{H}_{2} \mathrm{O}, \mathrm{NaOH}$, and $\mathrm{Na}_{2} \mathrm{CO}_{3}$ were purchased from Sinopharm Chemical Reagent Co., Ltd. (China). 1-Naphthylacetic acid (NAA) and indole-3-butyric acid (IBA) were obtained from Aladdin Reagent Co., Ltd. (China). All reagents were used as raw materials without further purification. $\mathrm{CO}_{2}$-free deionized water was used throughout the experimental processes.

2.2. Synthesis of $M g A l-N A A / I B A-L D H s$. The $\mathrm{MgAl}-\mathrm{CO}_{3}-$ LDHs was synthesized by the coprecipitation method reported previously [26]. The NAA/IBA cointercalation into MgAl-LDHs was prepared by coprecipitation method as follows. Firstly, 0.02 mole NAA and 0.02 mole IBA dissolved in $100 \mathrm{~mL}$ decarbonated water and the $\mathrm{pH}$ was adjusted to about 7 using $1 \mathrm{~mol} / \mathrm{L} \mathrm{NaOH}$. A $50 \mathrm{~mL}$ mixture solution containing $0.8 \mathrm{~mol} / \mathrm{L} \mathrm{Mg}\left(\mathrm{NO}_{3}\right)_{2} \cdot 6 \mathrm{H}_{2} \mathrm{O}$ and $0.3 \mathrm{~mol} / \mathrm{L}$ $\mathrm{Al}\left(\mathrm{NO}_{3}\right)_{3} \cdot 9 \mathrm{H}_{2} \mathrm{O}(\mathrm{Mg} / \mathrm{Al}$ molar ratio $=2: 1)$ was slowly added to abovementioned NAA-IBA mixture solution at room temperature with vigorously stirring under $\mathrm{N}_{2}$ atmosphere to prevent the formation of $\mathrm{MgAl}-\mathrm{CO}_{3}$-LDHs. The $\mathrm{pH}$ of the reaction mixture was adjusted $10.0 \pm 0.2$ by dropwise addition of $1 \mathrm{~mol} / \mathrm{L} \mathrm{NaOH}$ solution. Then the resulting slurry was crystallized at $70^{\circ} \mathrm{C}$ for $48 \mathrm{~h}$. The white precipitate was isolated by filtration, washed with hot decarbonated water several times, and dried at $80^{\circ} \mathrm{C}$ for $24 \mathrm{~h}$. For comparison, the NAA and IBA intercalated individually LDHs were also prepared by a standard coprecipitation method.

2.3. Characterization. X-ray diffraction (XRD) patterns of the samples were collected using a Bruker D8 Advance $\mathrm{XRD}$ diffractometer at $\mathrm{Cu} \mathrm{K} \alpha$ radiation and a fixed power source $(40 \mathrm{kV}$ and $40 \mathrm{~mA}, \lambda=1.5406 \AA$ ). Fourier transform infrared spectroscopy (FT-IR) were recorded in the range $400-4000 \mathrm{~cm}^{-1}$ on a Nicolet NEXUS 470 Fourier transform infrared spectrophotometer using $\mathrm{KBr}$ pellet technique. Thermogravimetry and differential thermal analysis (TGDTA) curves were obtained on a NETZSCH STA 449C instrument in the temperature range of $30-700^{\circ} \mathrm{C}$ with a heating rate of $10^{\circ} \mathrm{C} \mathrm{min}^{-1}$ in $\mathrm{N}_{2}$ atmosphere. The specific surface area and pore-size distribution were evaluated using the nitrogen adsorption (Quantachrome Autosorb 1-C). A scanning electron microscope (FEI NOVA NanoSEM 450) was used to study the surface morphology of sample. The compositions of MgAl-NAA/IBA-LDHs were determined from elemental CHON analysis with Vario EL III analyzer (Elementar) and $\mathrm{Mg}, \mathrm{Al}$ elemental analysis with inductively coupled plasma atomic emission spectrometer (ICP-AES) (PerkinElmer, OPTIMA 8000 DV), respectively.

2.4. Measurements of Total Release Amount of NAA and IBA in MgAl-NAA/IBA-LDHs Nanohybrids. To measure the release performances of NAA and IBA from MgAl-NAA/IBA-LDHs, $0.05 \mathrm{~g}$ of NAA and IBA cointercalation LDHs nanohybrid powder was dispersed in $500 \mathrm{~mL}$ water/ethanol solution with volume ratio 9:1 under magnetic stirring [12]. At specified time intervals, $2 \mathrm{~mL}$ of solution was removed and filtered through a $0.45 \mu \mathrm{m}$ microfiltration membrane and the total contents of NAA and IBA were determined by monitoring the absorbance at $280 \mathrm{~nm}$ with UV-vis spectroscopy to obtain the total release amounts $\left(q_{t}\right)$ of NAA and IBA from LDHs nanohybrids and in turn to calculate the accumulated percent releases $\left(X_{t}\right)$ of NAA and IBA from the nanohybrids. Release tests were performed in triplicate and the results were recorded as an average.

\section{Results and Discussion}

The molecular structures of NAA and IBA are given in Figures $1(\mathrm{a})$ and $1(\mathrm{~b})$, respectively. The formation of carboxylate anion was done by dissolving the acid in $\mathrm{NaOH}$ solution and the anion was intercalated between inorganic lamella of the MgAl-LDHs as evidence from powder X-ray and FT-IR studies and will be discussed later.

3.1. X-Ray Diffraction. XRD patterns of the $\mathrm{MgAl}-\mathrm{CO}_{3}-$ LDHs, MgAl-NAA-LDHs, MgAl-IBA-LDHs, and MgAlNAA/IBA-LDHs are shown in Figure 2. The XRD pattern of the contrast $\mathrm{MgAl}-\mathrm{CO}_{3}$-LDHs (Figure 1(b)) exhibits typical characteristics of the LDHs phase corresponding to the basal spacing of $0.75 \mathrm{~nm}$, which agrees well with the literature data [27]. After intercalation, the $d$-spacings of MgAl-NAA-LDHs, MgAl-IBA-LDHs, and MgAl-NAA/IBA-LDHs are expanded to $1.95 \mathrm{~nm}, 2.01 \mathrm{~nm}$, and $2.00 \mathrm{~nm}$, respectively.

Based on the basal spacing $d_{003}$ of $2.00 \mathrm{~nm}$ for MgAlNAA/IBA-LDH observed by XRD and subtracting the thickness of brucite layer $(0.48 \mathrm{~nm})$ the gallery height is calculated to be $1.52 \mathrm{~nm}$, which is bigger than that of NAA $(0.70 \mathrm{~nm})$ and IBA anions $(0.85 \mathrm{~nm})$. However, according to the size of IBA and NAA, a probable morphology of IBA and NAA molecules in the gallery of NAA-LDHs, IBA-LDHs, and cointercalation LDHs was proposed, as illustrated in Figures S1, S2, and S3, available online at http://dx.doi.org/10.1155/2014/862491. The gallery height of NAA/IBA cointercalation LDHs is smaller than the double sizes of the IBA anions and little bigger than the double sizes of the NAA anions. So, as shown in Figure S3, it was suspected that NAA and IBA anions located in the form of bilayer arrangement by turning the functional group on the contrary and opposing the fields of aromatic ring mutually by $\pi-\pi$ interaction [28].

3.2. Fourier Transform Infrared Spectroscopy. Figure 3 shows the FT-IR spectra of MgAl-CO ${ }_{3}$-LDHs, MgAl-NAA-LDHs, MgAl-IBA-LDHs, and MgAl-NAA/IBA-LDHs. In the spectrum of the $\mathrm{MgAl}-\mathrm{CO}_{3}-\mathrm{LDH}$ precursor, shown in Figure 3(a), the absorption band around 3450 and $1360 \mathrm{~cm}^{-1}$ can be ascribed to the characteristic peaks of the $\mathrm{MgAl}-\mathrm{CO}_{3}$ LDHs [28]. The FT-IR spectrum characteristic absorption peaks of NAA and IBA are shown in Figures S4 and S5, respectively. As shown in Figure 3, the asymmetric stretching band of $-\mathrm{COOH}$ in NAA and IBA at about $1695 \mathrm{~cm}^{-1}$ moves markedly toward low wavenumber (about $1553 \mathrm{~cm}^{-1}$ ) in the 
<smiles>O=C(O)Cc1cccc2ccccc12</smiles>

(a)<smiles>O=C(O)CCCc1c[nH]c2ccccc12</smiles>

(b)

FIGURE 1: Molecular structure of 1-naphthylacetic acid (a) and indole-3-butyric acid (b).

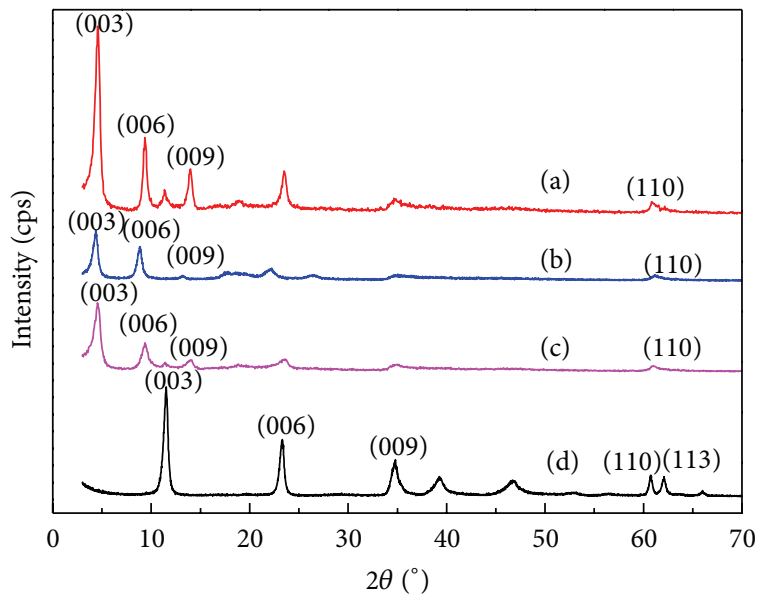

FIgURE 2: XRD patterns of (a) MgAl-NAA-LDHs, (b) MgAl-IBALDHs, (c) MgAl-NAA/IBA-LDHs, and (d) MgAl-CO ${ }_{3}$-LDHs.

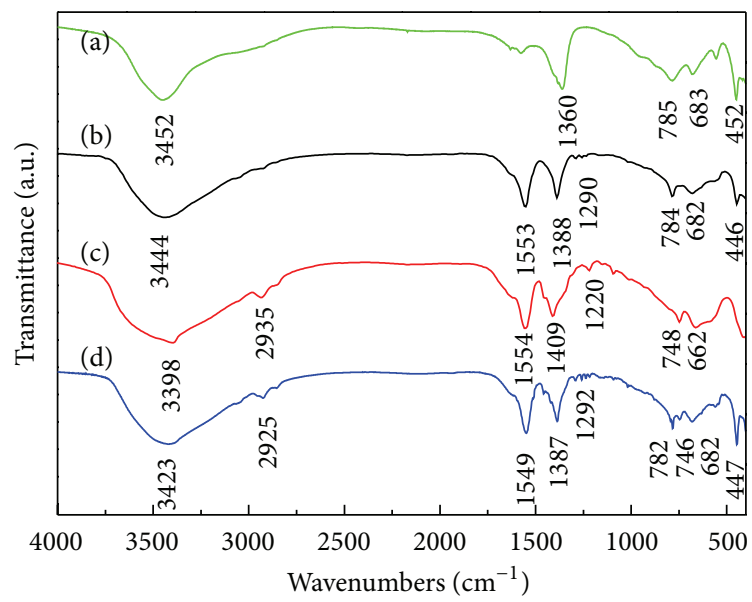

Figure 3: FT-IR spectra of (a) MgAl- $\mathrm{CO}_{3}$-LDHs, (b) MgAl-NAALDHs, (c) MgAl-IBA-LDHs, and (d) MgAl-NAA/IBA-LDHs.

nanohybrids, which can be ascribed to the ionization of NAA and IBA [12].

3.3. Surface Property. The isotherms of nitrogen adsorption and desorption at $77 \mathrm{~K}$ for the MgAl-NAA and IBA-LDHs are

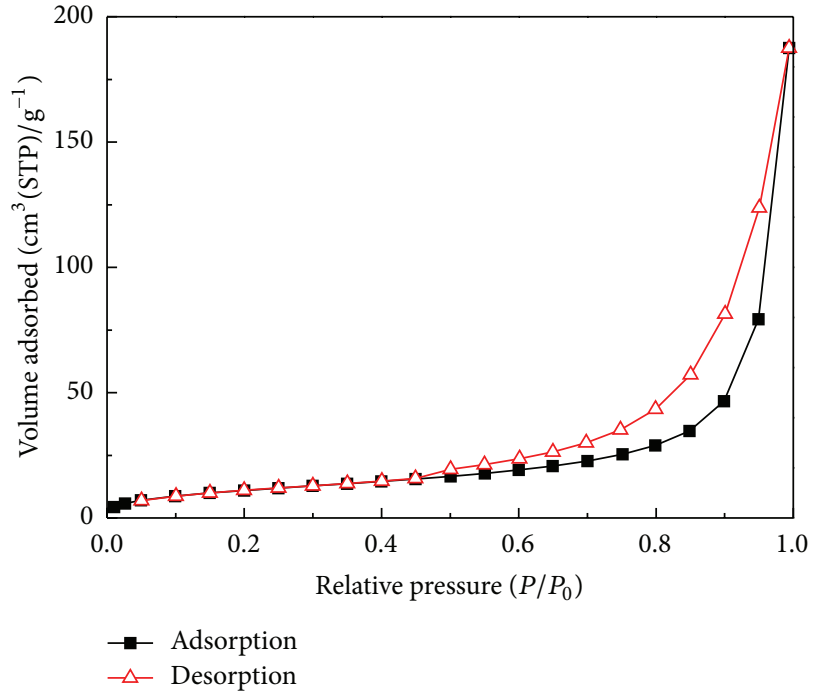

FIGURE 4: Adsorption-desorption isotherms of nitrogen gas for MgAl-NAA/IBA-LDHs.

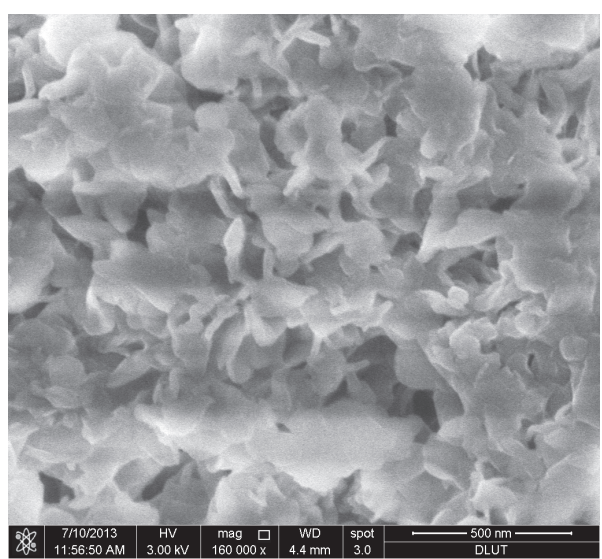

Figure 5: Scanning electron micrograph for MgAl-NAA/IBALDHs.

plotted in Figure 4. The BET surface area of MgAl-NAA/IBALDHs is $41.15 \mathrm{~m}^{2} \mathrm{~g}^{-1}$.

The SEM images of NAA/IBA-LDHs nanohybrid samples are shown in Figure 5. As can be seen, the NAA/IBA-LDHs particles are of typical plate-like shape with the lateral size of $50-100 \mathrm{~nm}$. 


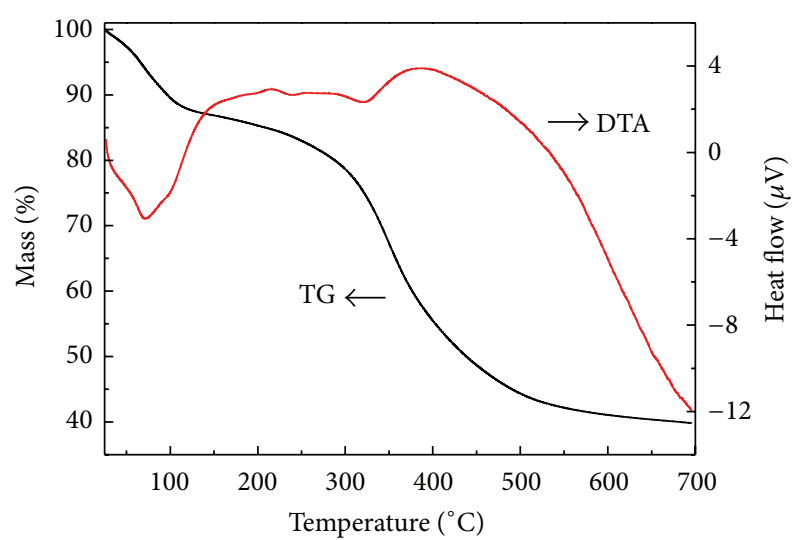

FIgURE 6: TG-DTA curve of MgAl-NAA/IBA-LDHs.

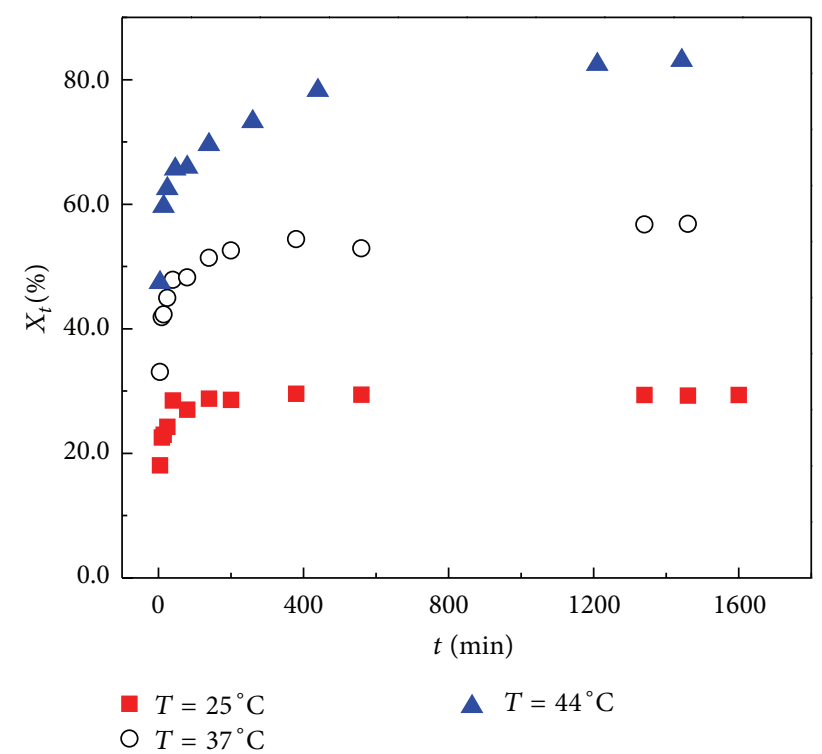

FIGURE 7: Release curves of MgAl-NAA/IBA-LDHs nanohybrid at $\mathrm{pH} 7$ and different temperatures $25^{\circ} \mathrm{C}, 37^{\circ} \mathrm{C}$, and $44^{\circ} \mathrm{C}$.

3.4. Elemental Analysis. The results of elemental analysis and the calculated structural formula of MgAl-NAA/IBA-LDHs are listed in Table 1. As listed in Table 1, the composition and general formula of MgAl-NAA/IBA-LDHs were determined from the ICP, CHON elemental analysis, and TG-DTA analysis. The molar ratio of $\mathrm{Mg}$ to $\mathrm{Al}$ is close to the expected value (theoretical of 2.0), indicating that the reaction was complete during the reaction of coprecipitation.

3.5. Thermal Stability of Nanohybrids. Figure 6 demonstrates TG-DTA curve of MgAl-NAA/IBA-LDHs nanohybrids. The TG-DTA curves of NAA and IBA are shown in Figures S6 and S7. For NAA and IBA cointercalated LDHs, there are three mass-loss stages in TG curve of MgAl-NAA/IBALDHs nanohybrids. The endothermic peaks around $70^{\circ} \mathrm{C}$ and $240^{\circ} \mathrm{C}$ in the DTA curve correspond to the removal of absorbed water and interlayer water [29]. With an increase of

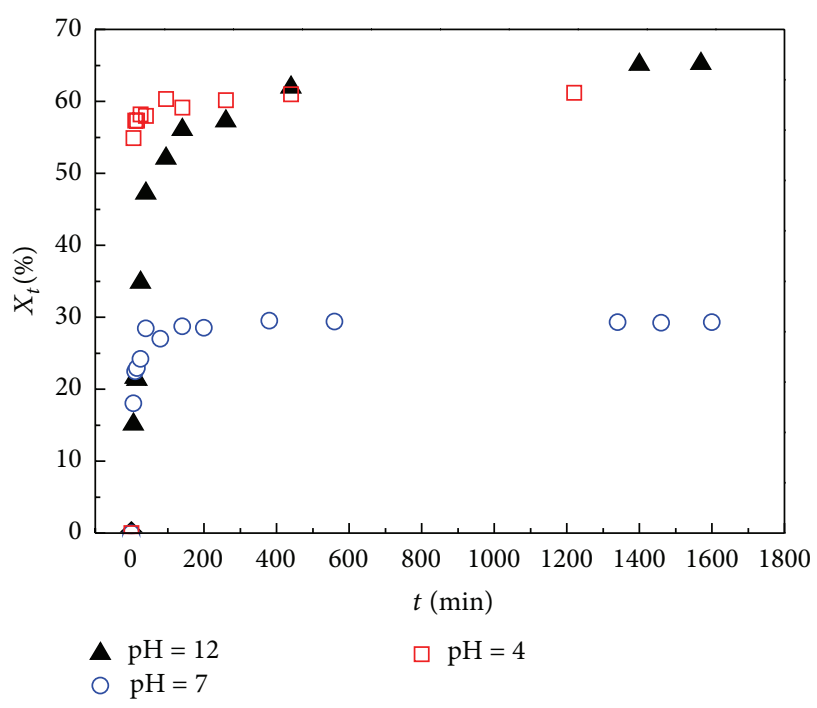

Figure 8: Release curves of MgAl-NAA/IBA-LDHs nanohybrid at $25^{\circ} \mathrm{C}$ and various $\mathrm{pH} 4,7$, and 12 .

temperature, an exothermic peak around $380^{\circ} \mathrm{C}$ in DTA curve was observed, showing the decomposition of NAA and IBA.

\subsection{Release of NAA and IBA from MgAl-NAA/IBA-LDHs Nanohybrids}

3.6.1. Effect of Temperature on NAA and IBA Total Release. Three different temperatures at 25,37 , and $44^{\circ} \mathrm{C}$ were selected to observe the effect on the total release of NAA and IBA from MgAl-NAA/IBA-LDHs nanohybrid. For temperature of $25^{\circ} \mathrm{C}$, the total release of NAA and IBA was initially rapid in the first 100 minutes and then followed by a more gradual release shown in Figure 7. In addition, an increase of temperature induces the increase of NAA and IBA total release extent, indicating that the release process was an endothermic reaction [12].

3.6.2. Effect of Solution $p H$ Value on NAA and IBA Total Release. Figure 8 shows the release profile of NAA and IBA from MgAl-NAA/IBA-LDHs nanohybrid at various initial $\mathrm{pH}$ values. The total amounts of NAA and IBA release at $\mathrm{pH}$ 4 and 12 were found to be higher than that at $\mathrm{pH} 7$.

3.6.3. Effect of Electrolyte Type on NAA and IBA Total Release. The release profiles of NAA and IBA from MgAl-NAA/IBALDHs nanohybrids into the aqueous solutions of $\mathrm{Na}_{2} \mathrm{CO}_{3}$, $\mathrm{Na}_{2} \mathrm{SO}_{4}$, and $\mathrm{NaCl}(0.01 \mathrm{M})$ are shown in Figure 9. As we can see, the presence of salts may increase the release rate and accumulate release amount of NAA and IBA. The release of NAA and IBA into salt aqueous solution was found to be dependent on the anion in the aqueous solution in the order of $\mathrm{CO}_{3}{ }^{2-} \approx \mathrm{SO}_{4}{ }^{2-}>\mathrm{Cl}^{-}$with the percentage release of 52,51 , and $47 \%$, which is because the exchange ability of $\mathrm{CO}_{3}{ }^{2-}$ for NAA and IBA is higher than those of $\mathrm{SO}_{4}{ }^{2-}$ and $\mathrm{Cl}^{-}$[30]. The total release of NAA and IBA from nanohybrids 
TABLE 1: Basal spacing, chemical composition, and surface properties of prepared nanohybrids.

\begin{tabular}{|c|c|c|c|c|c|c|c|}
\hline Sample & $d(\AA)$ & $\begin{array}{l}\mathrm{Mg} / \mathrm{Al} \\
\text { ratio }^{\mathrm{a}}\end{array}$ & $\begin{array}{c}\text { NAA } \\
(w t \%)^{b}\end{array}$ & $\begin{array}{c}\text { IBA } \\
(\mathrm{wt} \%)^{\mathrm{b}}\end{array}$ & $\begin{array}{c}\text { BET surface } \\
\text { area } \\
\left(\mathrm{m}^{2} \mathrm{~g}^{-1}\right)\end{array}$ & $\begin{array}{c}\text { BJH } \\
\text { desorption } \\
\text { pore volume } \\
\left(\mathrm{m}^{3} \mathrm{~g}^{-1}\right)\end{array}$ & $\begin{array}{c}\text { BET average } \\
\text { pore } \\
\text { diameter } \\
(\AA)\end{array}$ \\
\hline $\begin{array}{l}\text { MgAl-NAA/IBA- } \\
\text { LDHs }\end{array}$ & 20.1 & 2.23 & 22.1 & 22.6 & 41.15 & 0.291 & 28.3 \\
\hline \multicolumn{8}{|c|}{ Chemical composition $^{\mathrm{c}}$} \\
\hline \multicolumn{8}{|c|}{$\mathrm{Mg}_{0.69} \mathrm{Al}_{0.31}(\mathrm{OH})_{2}(\mathrm{NAA})_{0.16}(\mathrm{IBA})_{0.15} \cdot 0.86 \mathrm{H}_{2} \mathrm{O}$} \\
\hline
\end{tabular}

acalculated from ICP data.

bcalculated from UV-vis data, CHON analysis.

ccalculated from CHON analysis, UV-vis, ICP, and TG-DTA data.

TABLE 2: The rate constant of fitting the release data to pseudo-second-order kinetics model.

\begin{tabular}{|c|c|c|c|c|}
\hline$T\left({ }^{\circ} \mathrm{C}\right)$ & $\mathrm{pH}$ & Medium & $k_{2}\left(\mathrm{~min}^{-1} \cdot \mathrm{mg}^{-1} \cdot \mathrm{g}\right)$ & $r^{2}$ \\
\hline 25 & 7 & water & 0.105 & 0.9999 \\
\hline 37 & 7 & water & 0.160 & 0.9995 \\
\hline 44 & 7 & water & 0.256 & 0.9995 \\
\hline 25 & 4 & water & 0.130 & 0.9999 \\
\hline 25 & 12 & water & 0.403 & 1 \\
\hline 25 & 7 & $\mathrm{NaCl}$ & 0.126 & 0.9999 \\
\hline 25 & 7 & $\mathrm{Na}_{2} \mathrm{SO}_{4}$ & 0.235 & 1 \\
\hline 25 & 7 & $\mathrm{Na}_{2} \mathrm{CO}_{3}$ & 0.262 & 1 \\
\hline
\end{tabular}

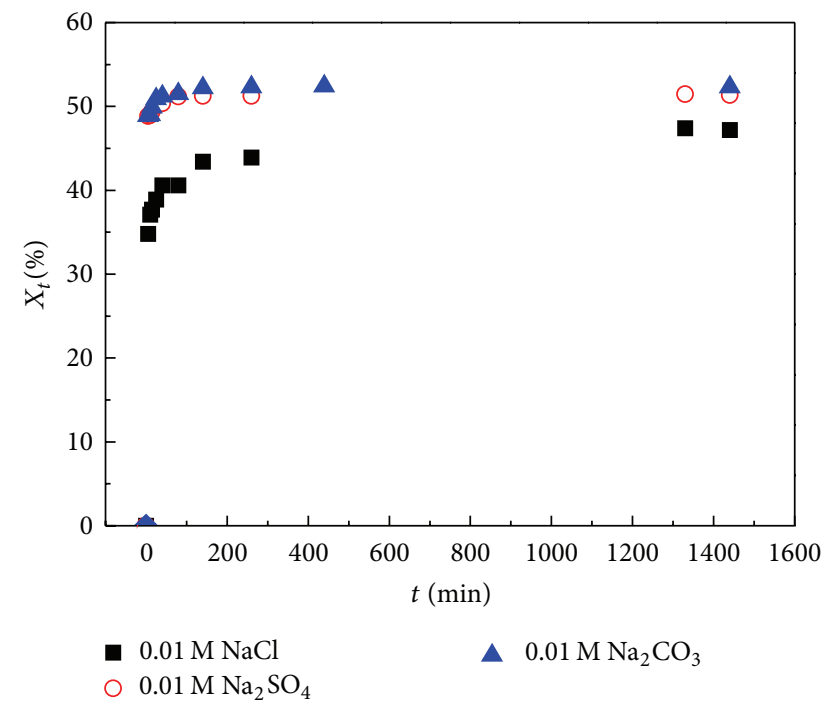

FIGURE 9: Release properties of MgAl-NAA/IBA-LDHs nanohybrid at different salt solutions $\left(0.01 \mathrm{M}, \mathrm{pH} 7,25^{\circ} \mathrm{C}\right)$.

should involve dissolution of nanohybrids as well as ion exchange between the intercalated NAA and IBA anions and salt anions.

3.7. Release Kinetics of NAA and IBA from NAA/IBA-LDHs Nanohybrids. Release kinetics of NAA and IBA has been evaluated with pseudo-first-order and pseudo-second-order models. Pseudo-first-order kinetic equation [12] may be represented in the linear form

$$
-\ln \left(1-X_{t}\right)=k_{1} t
$$

where $k_{1}$ is the rate constant of pseudo-first-order release kinetics. If the pseudo-first-order kinetics is applicable, the plot of $-\ln \left(1-X_{t}\right)$ versus $t$ will give a straight line, and the $k_{1}$ value can be obtained from the slope of the linear plot.

Pseudo-second-order kinetic equation may be represented in the linear form

$$
\frac{t}{X_{t}}=\frac{1}{k_{2} q_{e}}+t,
$$

where $q_{e}$ is equilibrium release amount, $k_{2}$ is the rate constant of pseudo-second-order release kinetics. If the pseudosecond-order kinetics is applicable, the plot of $t / X_{t}$ versus $t$ will give a straight line, which allows computation of $k_{2}$.

As shown in Figure 10, the $r^{2}$ values of release data fitting pseudo-second order model are in the range of 0.9995-1, while those with pseudo-first-order model are in the range of $0.4745-0.8303$. The rate constant $\left(k_{2}\right)$ and correlation coefficient $\left(r^{2}\right)$ values obtained from straight lines are listed in Table 2. It can be seen that the pseudo-second-order model is better satisfaction for describing the release kinetic processes of NAA and IBA than the MgAl-NAA/IBA-LDHs nanohybrids.

\section{Conclusion}

NAA and IBA simultaneous intercalated MgAl-layered double hydroxides (MgAl-NAA/IBA-LDHs) were successfully 


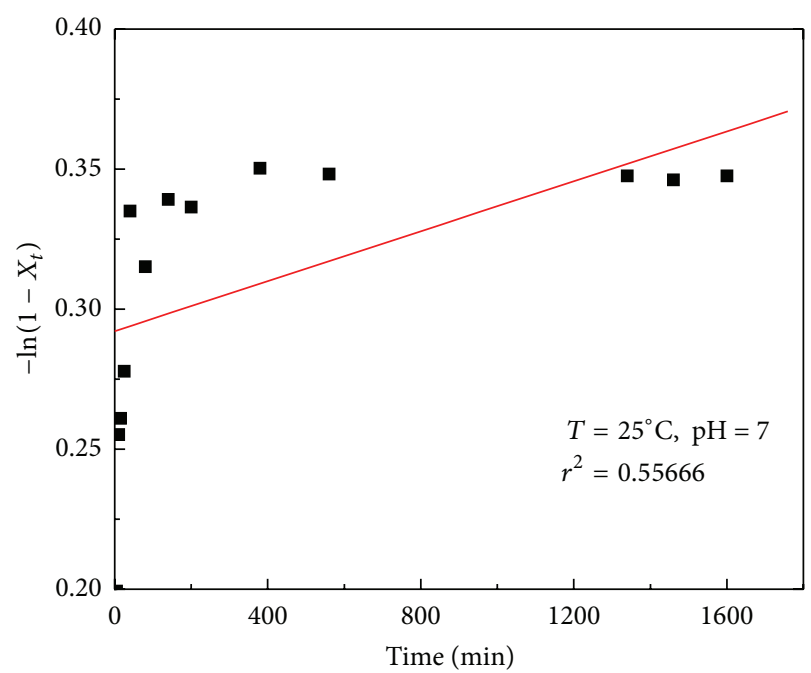

(a)

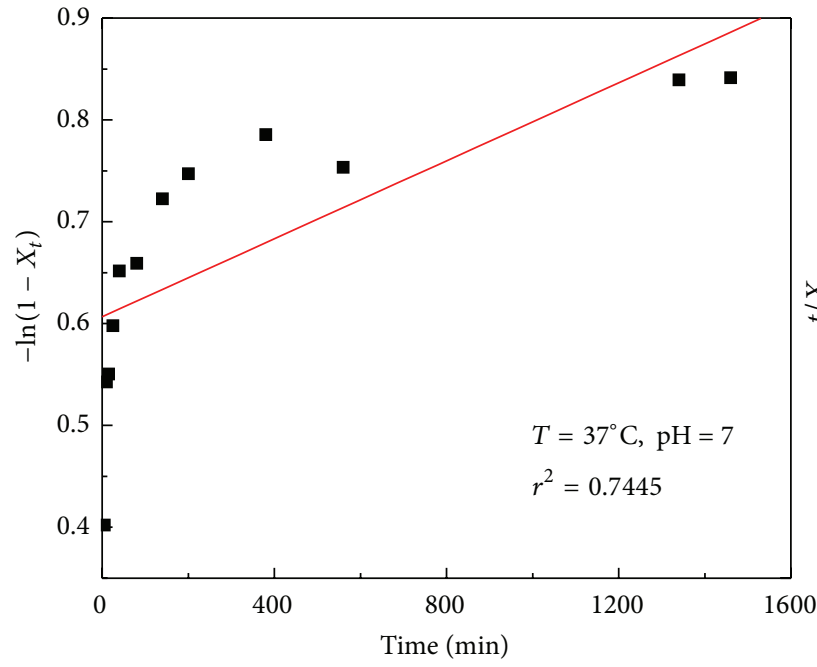

(b)

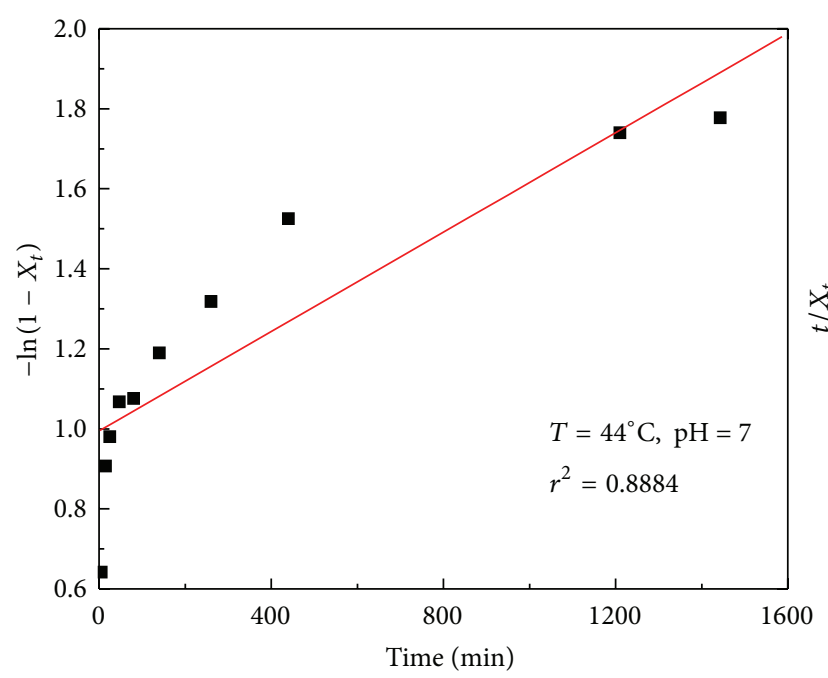

(c)

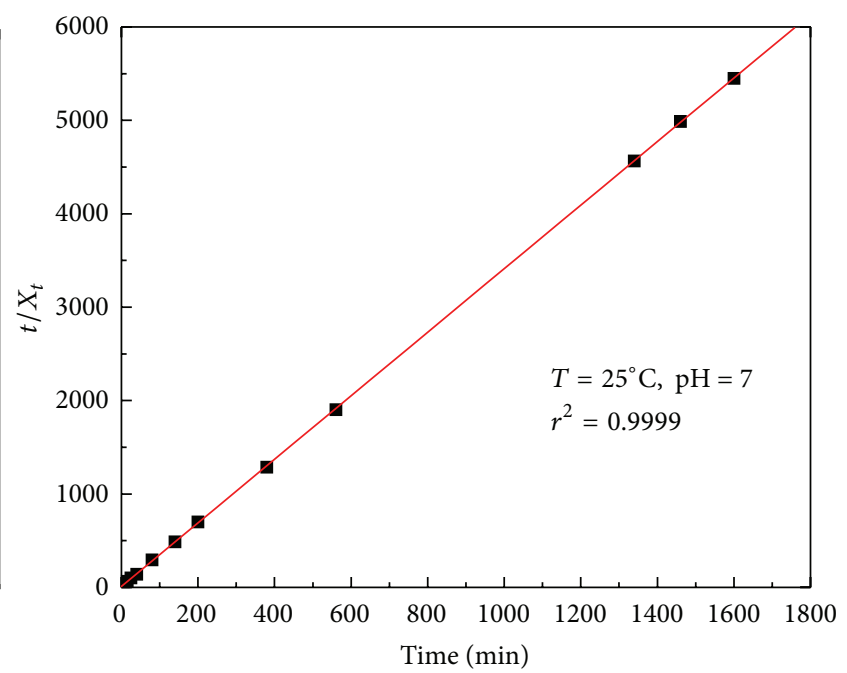

$\left(a^{\prime}\right)$

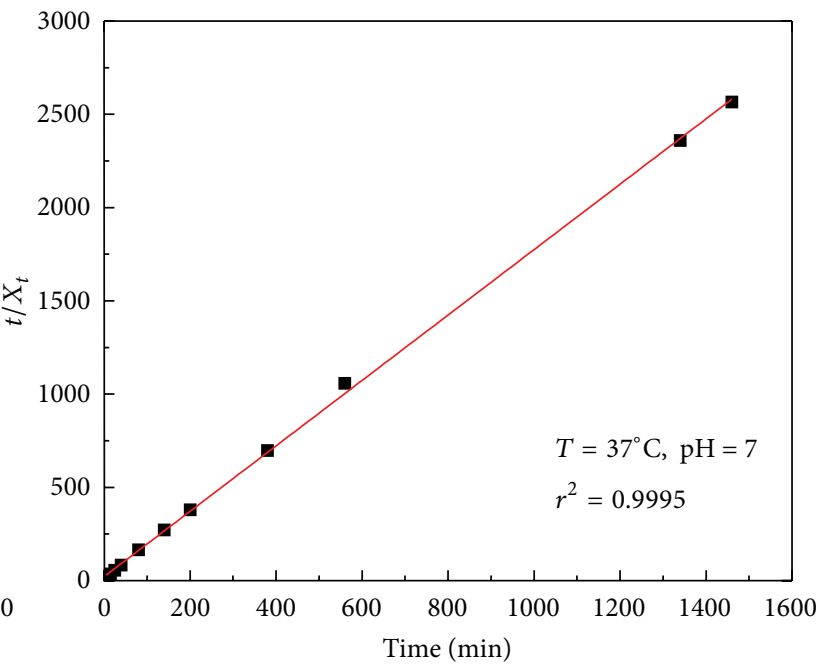

$\left(b^{\prime}\right)$

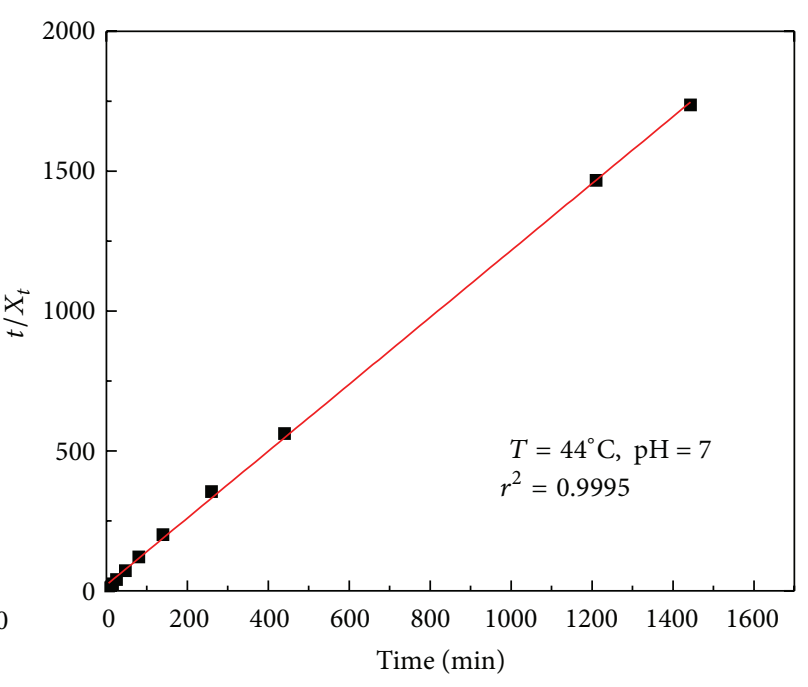

$\left(c^{\prime}\right)$

FIGURE 10: Continued. 


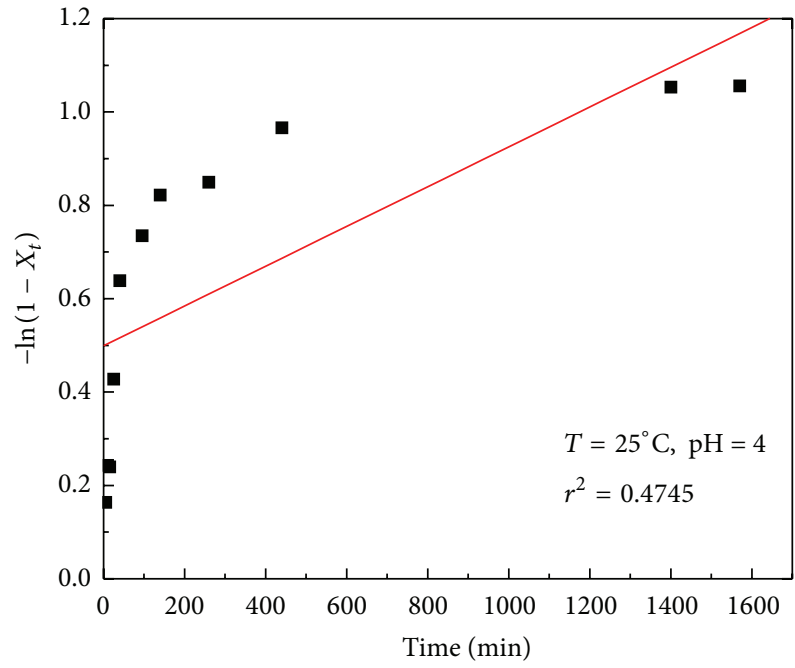

(d)

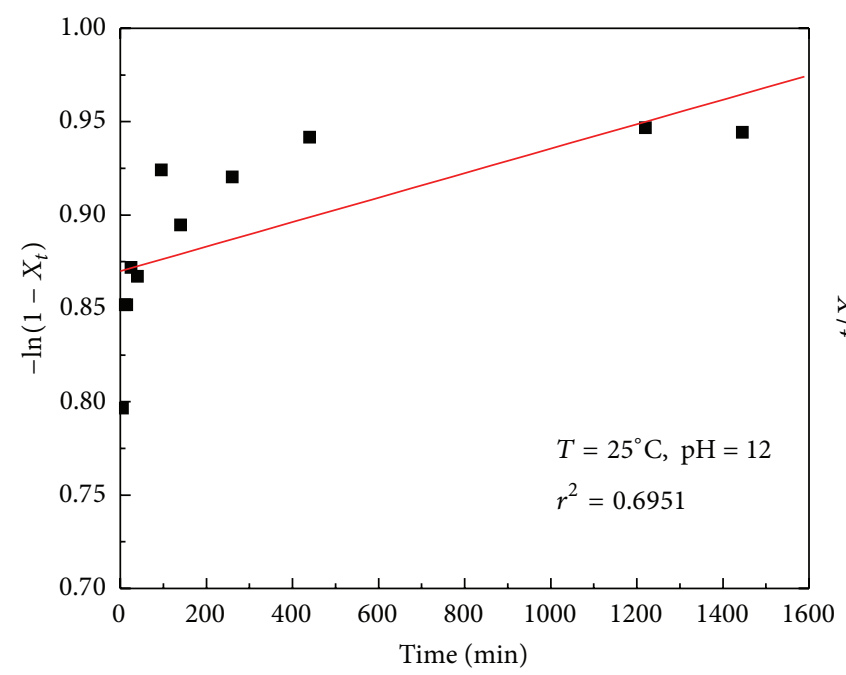

(e)

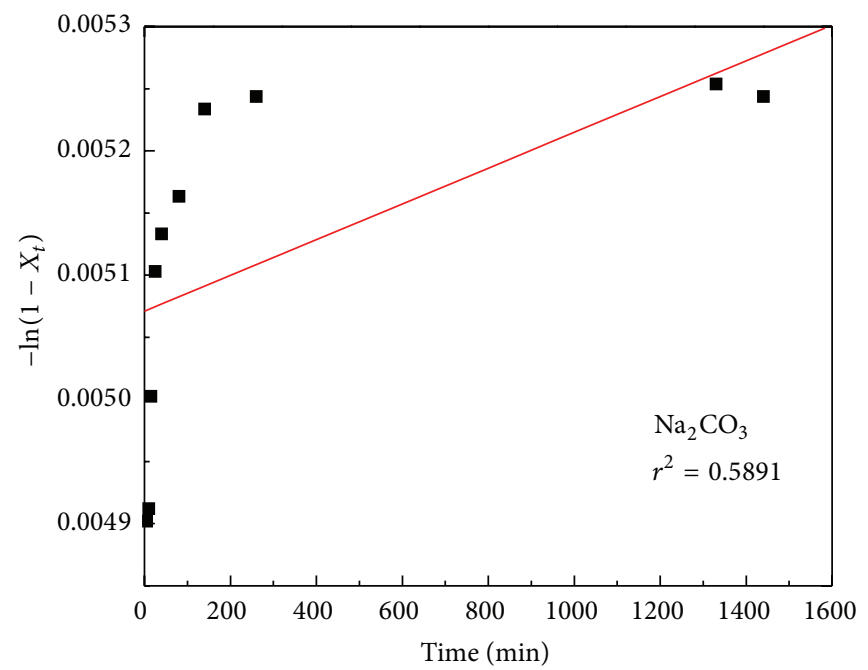

(f)

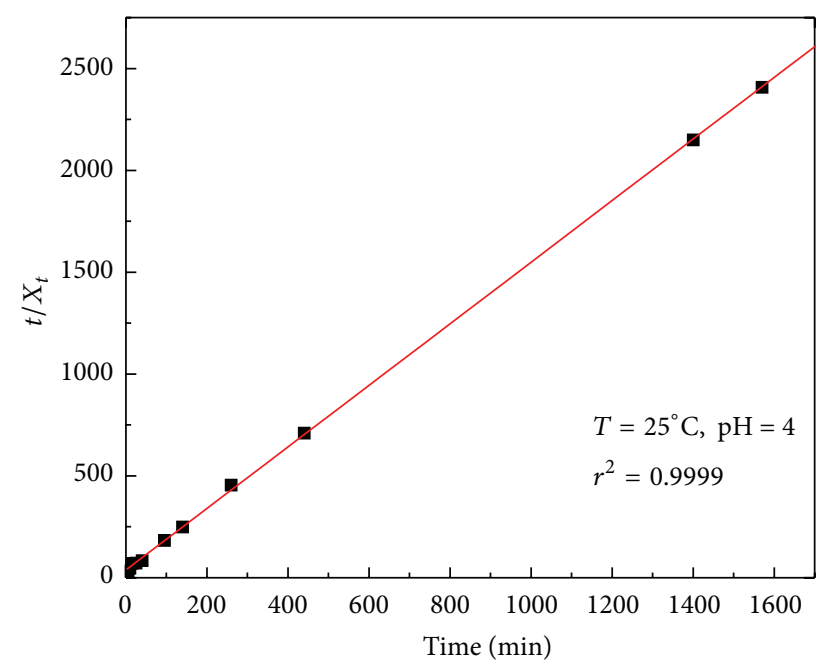

$\left(\mathrm{d}^{\prime}\right)$

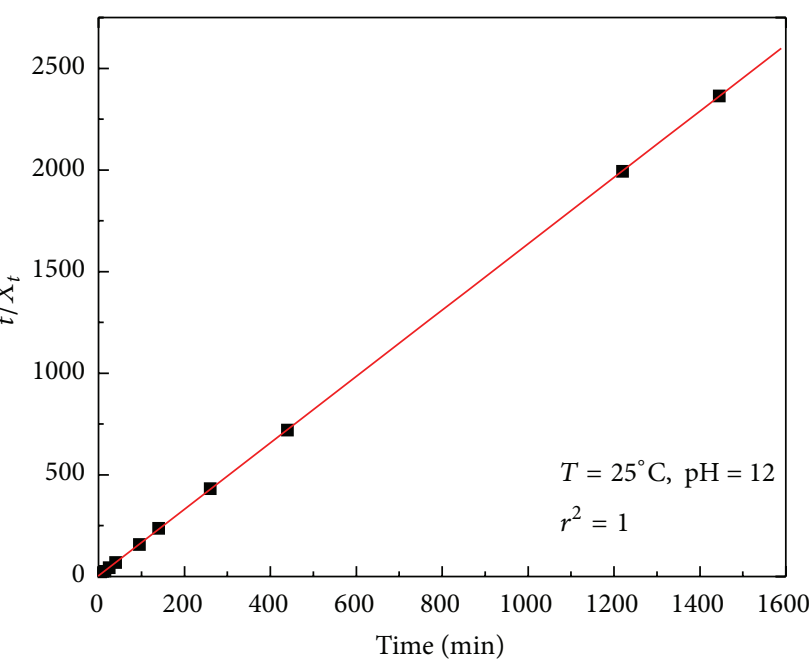

$\left(\mathrm{e}^{\prime}\right)$

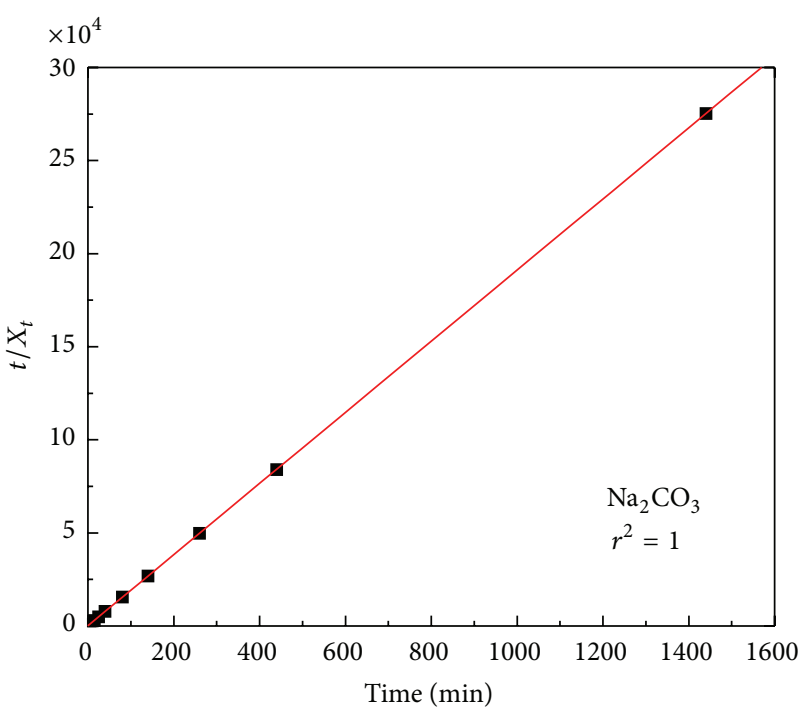

$\left(f^{\prime}\right)$

FIgure 10: Continued. 


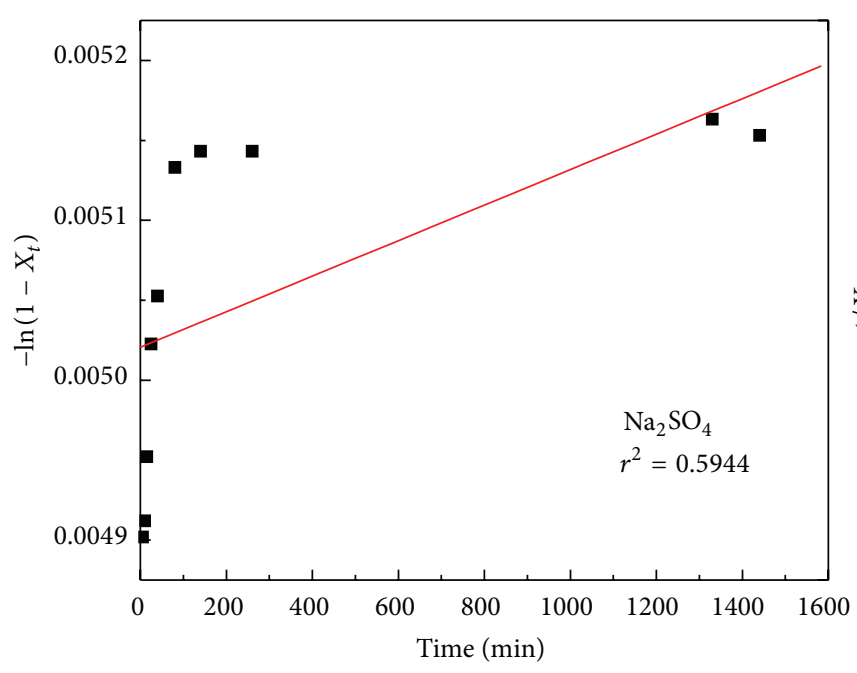

(g)

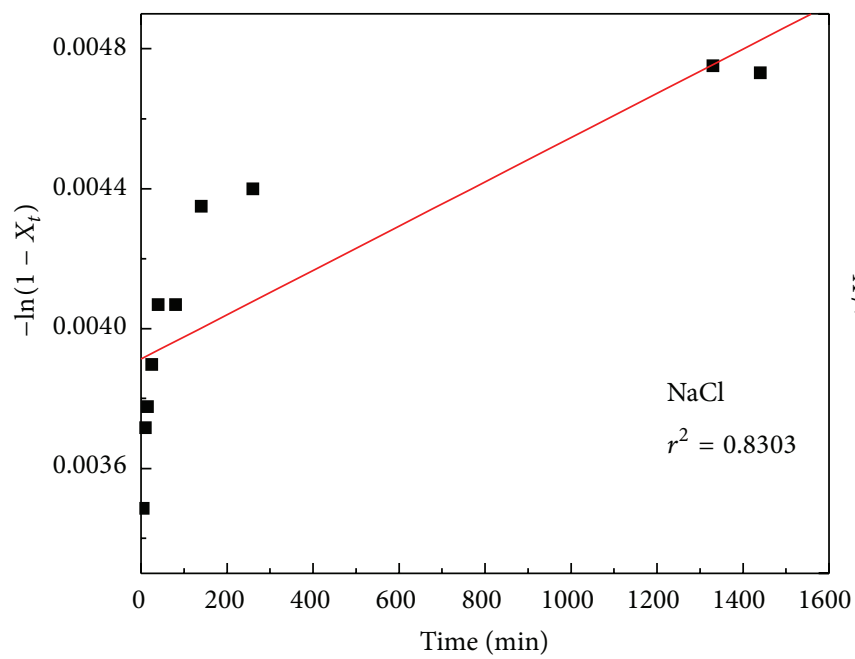

(h)

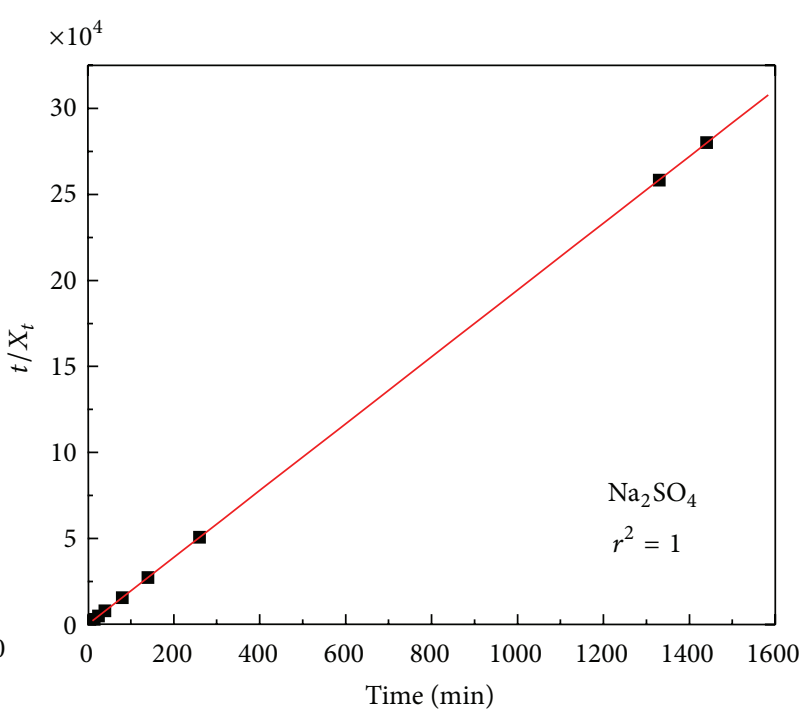

$\left(\mathrm{g}^{\prime}\right)$

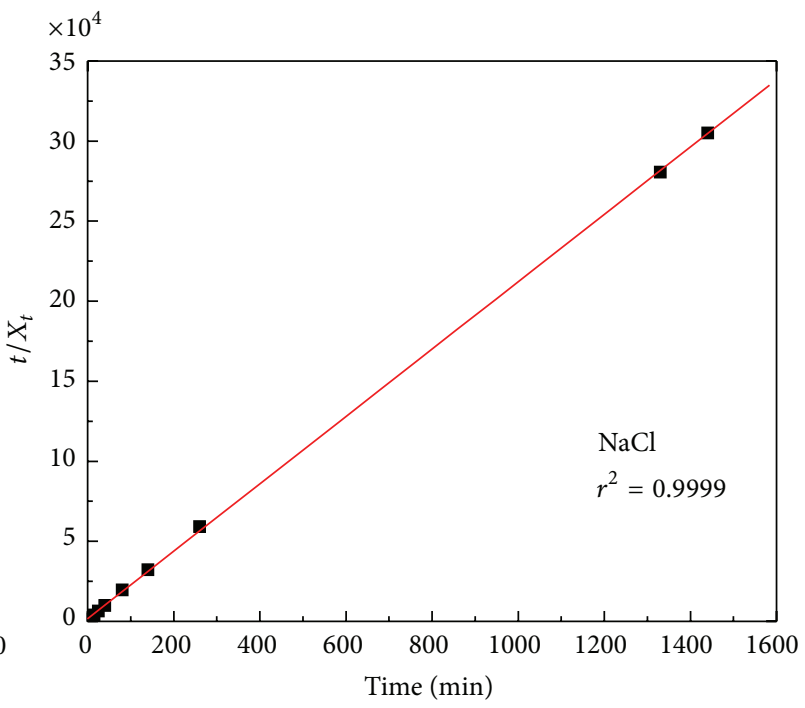

$\left(\mathrm{h}^{\prime}\right)$

FIGURE 10: Linear regression curves of NAA and IBA total release data fitting with first-order $(\mathrm{a}-\mathrm{h})$ and pseudo-second-order $\left(\mathrm{a}^{\prime}-\mathrm{h}^{\prime}\right)$ kinetic model for MgAl-NAA/IBA-LDHs nanohybrids.

synthesized by coprecipitation method. After intercalation of NAA and IBA, the interlayer distance of the nanohybrids is $2.00 \mathrm{~nm}$ and NAA and IBA anions located in the gallery of MgAl-LDHs with bilayer arrangement. The result shows that the release of NAA and IBA is dependent on temperature, $\mathrm{pH}$ value, and release medium. The nanohybrids possessed good controlled-release properties and the release of intercalated NAA and IBA from the nanohybrids fitted pseudo-secondorder model.

\section{Conflict of Interests}

The authors declare that there is no conflict of interests regarding the publication of this paper.

\section{Acknowledgment}

The authors greatly acknowledge the National Natural Science Foundation of China (no. 21106085).

\section{References}

[1] J. L. Müller, "Indole-3-butyric acid in plant growth and development," Plant Growth Regulation, vol. 32, no. 2-3, pp. 219-230, 2000.

[2] A. G. Ortolá, C. Monerri, and J. L. Guardiola, "The use of naphthalene acetic acid as a fruit growth enhancer in Satsuma mandarin: a comparison with the fruit thinning effect," Scientia Horticulturae, vol. 47, no. 1-2, pp. 15-25, 1991.

[3] S. Nafisi, F. Manouchehri, and M. Bonsaii, "Study on the interaction of glycyrrhizin and glycyrrhetinic acid with RNA," 
Journal of Photochemistry and Photobiology B: Biology, vol. 111, pp. 27-34, 2012.

[4] X. Qing, H. Wu, C. Nie et al., "Simultaneous determination of plant growth regulators in environmental samples using chemometrics-assisted excitation-emission matrix fluorescence: experimental study on the prediction quality of second-order calibration method," Talanta, vol. 103, pp. 86-94, 2013.

[5] A. Karadeniz, B. Kaya, B. Savas, and S. F. Topcuoglu, "Effects of two plant growth regulators, indole-3-acetic acid and $\beta$ naphthoxyacetic acid, on genotoxicity in Drosophila SMART assay and on proliferation and viability of HEK293 cells from the perspective of carcinogenesis," Toxicology and Industrial Health, vol. 27, no. 9, pp. 840-848, 2011.

[6] M. Ao, Y. Zhu, S. He et al., "Preparation and characterization of 1-naphthylacetic acid-silica conjugated nanospheres for enhancement of controlled-release performance," Nanotechnology, vol. 24, no. 3, Article ID 035601, 2013.

[7] S. Dubey, V. Jhelum, and P. K. Patanjali, "Controlled release agrochemicals formulations: a review," Journal of Scientific \& Industrial Research, vol. 70, no. 2, pp. 105-112, 2011.

[8] M. Z. B. Hussein, Z. Zainal, A. H. Yahaya, and D. W. V. Foo, "Controlled release of a plant growth regulator, $\alpha$ naphthaleneacetate from the lamella of $\mathrm{Zn}$-Al-layered double hydroxide nanocomposite," Journal of Controlled Release, vol. 82, no. 2-3, pp. 417-427, 2002.

[9] M. Z. B. Hussein, Z. Zainal, A. H. Yahaya, and D. W. V. Foo, "Microwave-assisted aging of organic-inorganic hybrid nanocomposite of $\alpha$-naphthaleneacetate in the lamella of $\mathrm{Zn}$ Al-layered double hydroxide," Journal of Materials Synthesis and Processing, vol. 10, no. 2, pp. 89-95, 2002.

[10] M. Z. B. Hussein and C. Long, "Synthesis of organo-mineral nanohybrid material: indole-2-carboxylate in the lamella of $\mathrm{Zn}$ Al-layered double hydroxide," Materials Chemistry and Physics, vol. 85, no. 2-3, pp. 427-431, 2004.

[11] J. Yang, Y. Han, M. Park, T. Park, S. Hwang, and J. Choy, "New inorganic-based drug delivery system of indole-3-acetic acidlayered metal hydroxide nanohybrids with controlled release rate," Chemistry of Materials, vol. 19, no. 10, pp. 2679-2685, 2007.

[12] D. Qiu and W. Hou, "Synthesis and characterization of indole3-butyric acid/hydrotalcite-like compound nanohybrids," Colloids and Surfaces A: Physicochemical and Engineering Aspects, vol. 336, no. 1-3, pp. 12-17, 2009.

[13] W. Li, D. Yan, R. Gao, J. Lu, M. Wei, and X. Duan, "Recent advances in stimuli-responsive photofunctional materials based on accommodation of chromophore into layered double hydroxide nanogallery," Journal of Nanomaterials, vol. 2013, Article ID 586462, 14 pages, 2013.

[14] A. D. C. Silva, A. L. F. de Souza, R. A. Simão, and L. F. B. Malta, “A simple approach for the synthesis of gold nanoparticles mediated by layered double hydroxide," Journal of Nanomaterials, vol. 2013, Article ID 357069, 6 pages, 2013.

[15] A. A. A. Ahmed, Z. A. Talib, and M. Z. Hussein, "Influence of metallic molar ratio on the electron spin resonance and thermal diffusivity of Zn-Al layered double hydroxide," Journal of Nanomaterials, vol. 2013, Article ID 639354, 9 pages, 2013.

[16] V. Rives, M. Arco, and C. Martín, "Layered double hydroxides as drug carriers and for controlled release of non-steroidal antiinflammatory drugs (NSAIDs): a review," Journal of Controlled Release, vol. 169, no. 1-2, pp. 28-39, 2013.

[17] S. H. Sarijo, S. A. I. S. M. Ghazali, M. Z. Hussein, and N. J. Sidek, "Synthesis of nanocomposite 2-methyl-4-chlorophenoxyacetic acid with layered double hydroxide: physicochemical characterization and controlled release properties," Journal of Nanoparticle Research, vol. 15, no. 1, Article ID 1356, 2013.

[18] A. D. Kevadiya, R. P. Thumbar, M. M. Rajput et al., "Montmorillonite/poly-( $\varepsilon$-caprolactone) composites as versatile layered material: reservoirs for anticancer drug and controlled release property," European Journal of Pharmaceutical Sciences, vol. 47, no. 1, pp. 265-272, 2012.

[19] T. H. Kim, H. J. Kim, and J. M. Oh, "Interlayer structure of bioactive molecule, 2-aminoethanesulfonate, intercalated into calcium-containing layered double hydroxides," Journal of Nanomaterials, vol. 2012, Article ID 987838, 7 pages, 2012.

[20] X. Wu, H. Li, S. Song, R. Zhang, and W. Hou, "Facile synthesis of camptothecin intercalated layered double hydroxide nanohybrids via a coassembly route," International Journal of Pharmaceutics, vol. 454, no. 1, pp. 453-461, 2013.

[21] X. Duan and D. G. Evans, Layered Double Hydroxides, Springer, Berlin, Germany, 2006.

[22] J. Choy, J. Park, S. Kwak, Y. Jeong, and Y. Han, "Layered double hydroxide as gene reservoir," Molecular Crystals and Liquid Crystals Science and Technology A, vol. 341, pp. 425-429, 2000.

[23] W. M. Kriven, S. Kwak, M. A. Wallig, and J. Choy, "Bioresorbable nanoceramics for gene and drug delivery," $M R S$ Bulletin, vol. 29, no. 1, pp. 33-37, 2004.

[24] M. Z. Hussein, N. S. S. A. Rahman, S. H. Sarijo, and Z. Zainal, "Synthesis of a monophasic nanohybrid for a controlled release formulation of two active agents simultaneously," Applied Clay Science, vol. 58, pp. 60-66, 2012.

[25] A. M. Bashi, M. Z. Hussein, Z. Zainal, M. Rahmani, and D. Tichit, "Simultaneous intercalation and release of 2,4-dichloroand 4-chloro-phenoxy acetates into $\mathrm{Zn} / \mathrm{Al}$ layered double hydroxide," Arabian Journal of Chemistry, 2012.

[26] S. Sasaki, Y. Yokohama, S. Aisawa, H. Hirahara, and E. Narita, "Intercalation of natural cyclodextrins into layered double hydroxide by calcination-rehydration reaction," Chemistry Letters, vol. 34, no. 8, pp. 1192-1193, 2005.

[27] Y. Feng, D. Li, Y. Wang, D. G. Evans, and X. Duan, "Synthesis and characterization of a UV absorbent-intercalated $\mathrm{Zn}-\mathrm{Al}$ layered double hydroxide," Polymer Degradation and Stability, vol. 91, no. 4, pp. 789-794, 2006.

[28] S. Li, Y. Shen, M. Xiao, D. Liu, L. Fa, and K. Wu, "Intercalation of 2,4-dihydroxybenzophenone-5-sulfonate anion into $\mathrm{Zn} / \mathrm{Al}$ layered double hydroxides for UV absorption properties," Journal of Industrial and Engineering Chemistry, 2013.

[29] W. Yang, Y. Kim, P. K. T. Liu, M. Sahimi, and T. T. Tsotsis, "A study by in situ techniques of the thermal evolution of the structure of a $\mathrm{Mg}-\mathrm{Al}-\mathrm{CO}_{3}$ layered double hydroxide," Chemical Engineering Science, vol. 57, no. 15, pp. 2945-2953, 2002.

[30] F. Cavani, F. Trifiro, and A. Vaccari, "Hydrotalcite-type anionic clays: preparation, properties and applications," Catalysis Today, vol. 11, no. 2, pp. 173-301, 1991. 

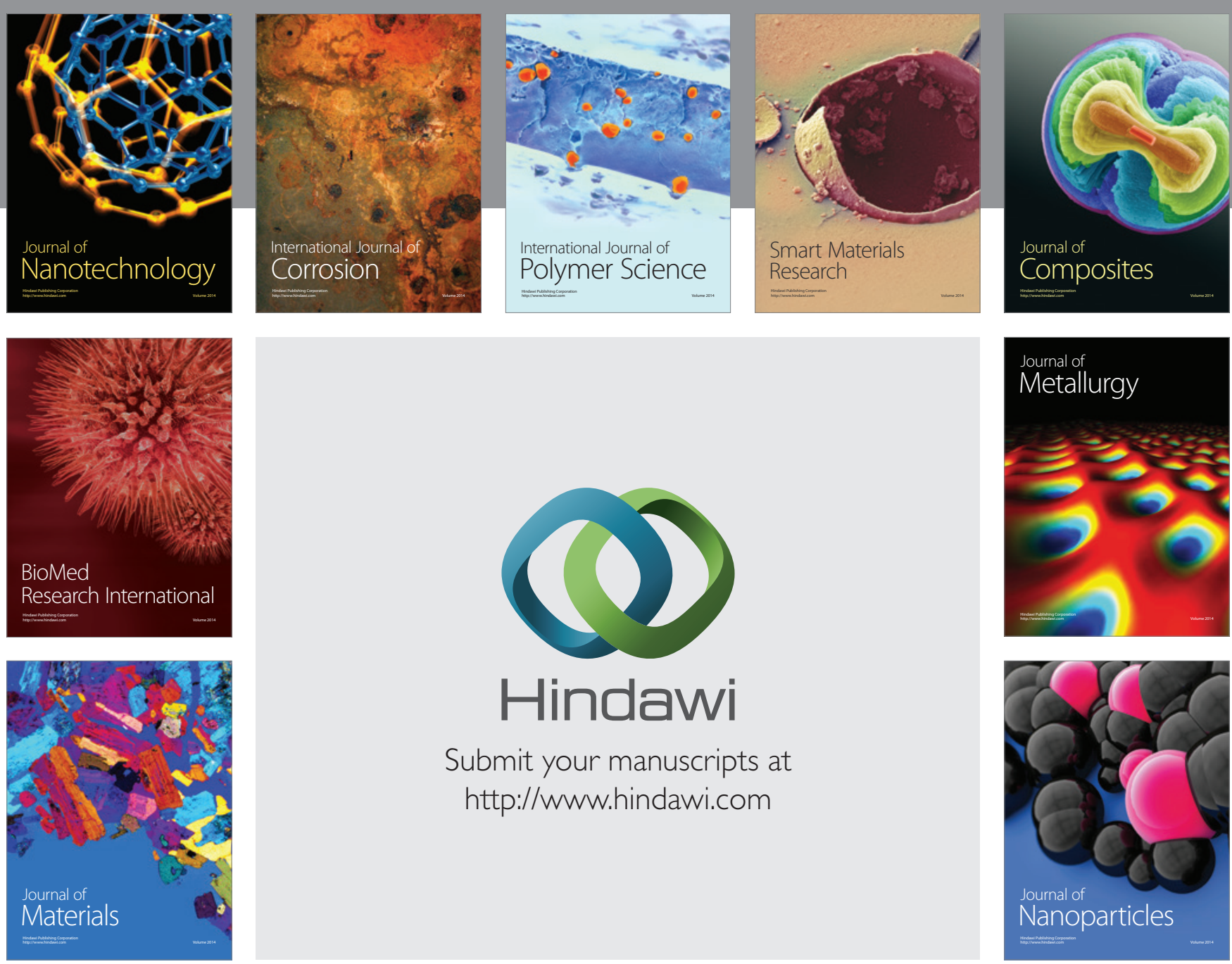

Submit your manuscripts at http://www.hindawi.com
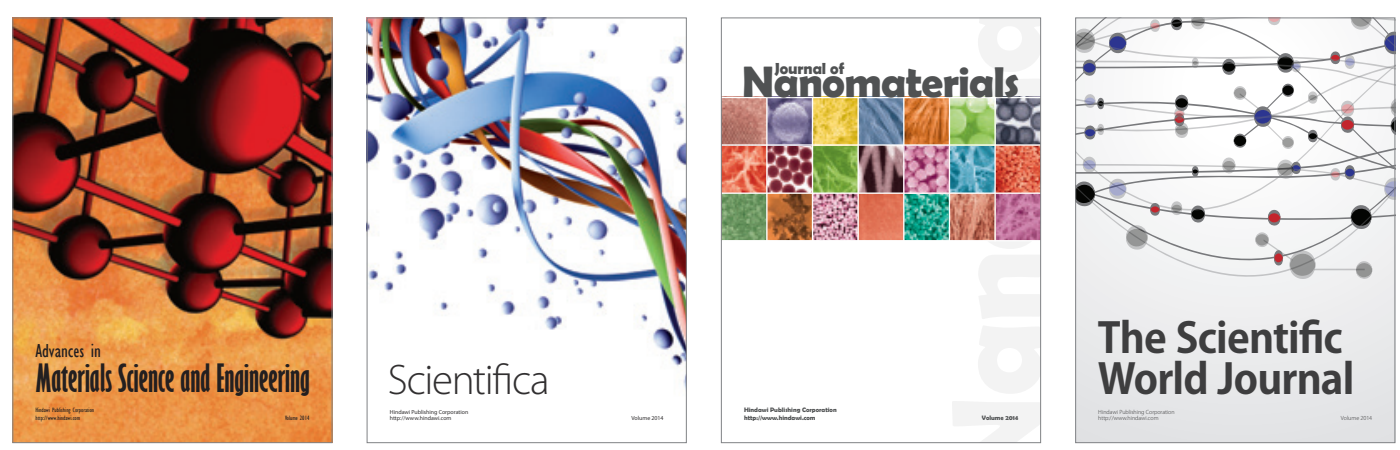

\section{The Scientific World Journal}
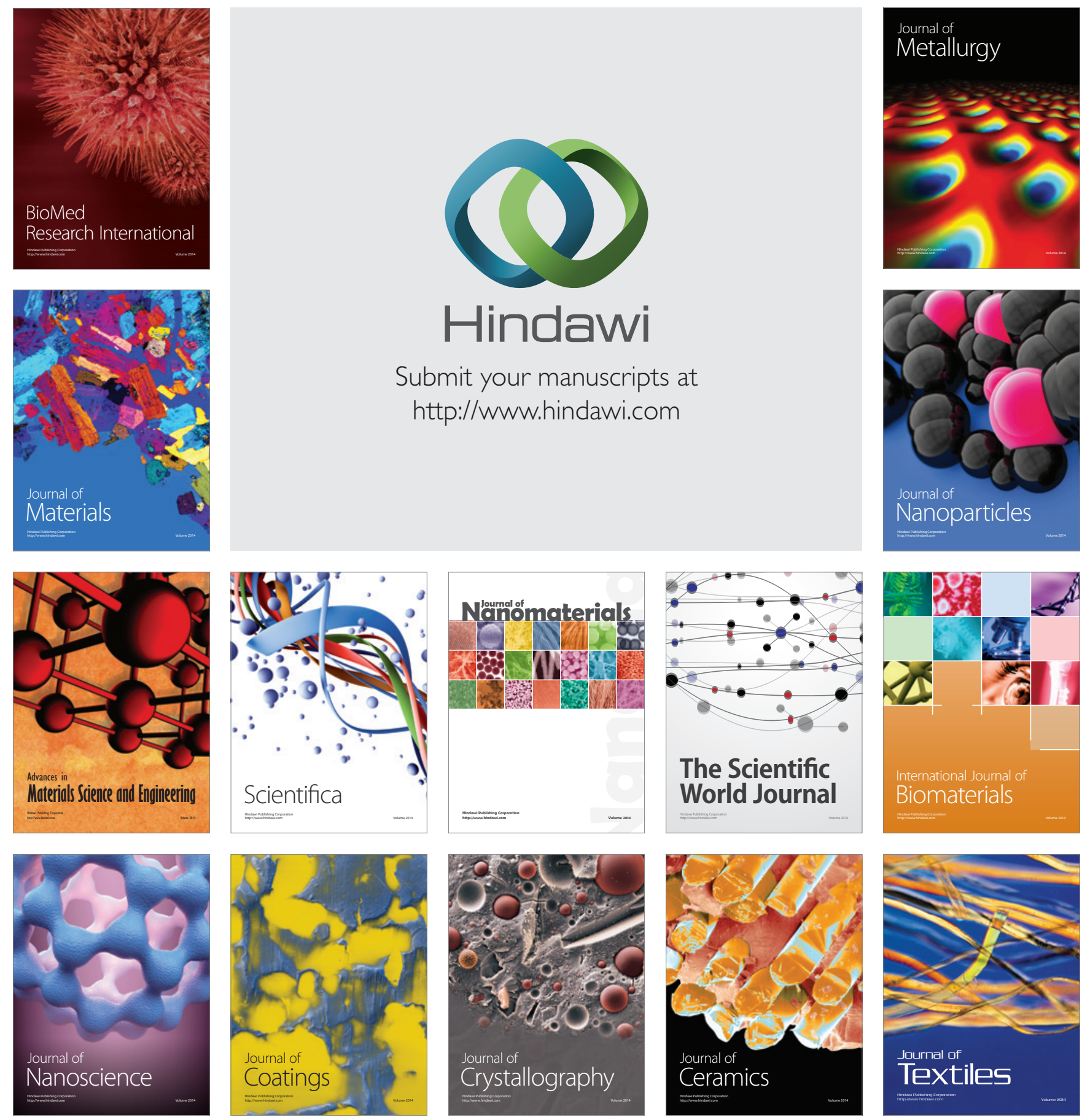